\title{
PMA/IONO affects diffuse large B-cell lymphoma cell growth through upregulation of A20 expression
}

\author{
WENXIU YANG ${ }^{1}$, YI LI $^{2}$, PINHAO LI ${ }^{1}$ and LINGLING WANG ${ }^{2}$ \\ ${ }^{1}$ Department of Pathology, Affiliated Hospital, Guizhou Medical University, Guiyang, Guizhou 550001; \\ ${ }^{2}$ Department of Pathology, Guizhou Medical University, Guiyang, Guizhou 550025, P.R. China
}

Received February 1, 2016; Accepted June 14, 2016

DOI: $10.3892 /$ or.2016.4899

\begin{abstract}
Diffuse large B-cell lymphoma (DLBCL) is a common non-Hodgkin lymphoma. A20 and mucosa-associated lymphoid tissue lymphoma translocation gene 1 (MALT1) are known to be related to DLBCL pathogenesis and progression. This study aimed to assess the effects of phorbol myristate acetate/ionomycin (PMA/IONO) on the growth and apoptosis of the DLBCL cell line OCI-LY1, and their associations with A20, MALT1 and survivin levels. Cell viability was assessed by MTT assay. Cell cycle distribution and apoptosis were evaluated using flow cytometry after incubation with Annexin V-FITC/propidium iodide (PI) and RNase/PI, respectively. Gene and protein expression levels were determined by quantitative real-time PCR and western blotting, respectively. To further determine the role of A20, this gene was silenced in the OCI-LY1 cell line by specific siRNA transfection. A20 protein levels were higher in the OCI-LY1 cells treated with PMA/IONO compared with the controls, and were positively correlated with the concentration and treatment time of IONO, but not with changes of PMA and MALT1. Meanwhile, survivin expression was reduced in the OCI-LY1 cells after PMA/IONO treatment. In addition, OCI-LY1 proliferation was markedly inhibited, with a negative correlation between cell viability and IONO concentration. In concordance, apoptosis rates were higher in the OCI-LY1 cells after PMA + IONO treatment. Cell cycle distribution differed between the OCI-LY1 cells with and without PMA/IONO treatment only at $24 \mathrm{~h}$, with increased cells in the G0/G1 stage after PMA/IONO treatment. These findings indicate that PMA/IONO promotes the apoptosis and inhibits the growth of DLBCL cells, in association with A20 upregulation. Thus, A20 may be a potential therapeutic target for DLBCL.
\end{abstract}

Correspondence to: Dr Wenxiu Yang, Department of Pathology, Affiliated Hospital, Guizhou Medical University, Guiyang, Guizhou 550001, P.R. China

E-mail:2916205472@qq.com

Key words: phorbol myristate acetate, ionomycin, diffuse large B-cell lymphoma cells, A20, cell proliferation

\section{Introduction}

Diffuse large B-cell lymphoma (DLBCL) accounts for $30-40 \%$ of adult non-Hodgkin lymphomas. According to its heterogeneity in clinical course, morphology, immunophenotype and genetics, DLBCL is subdivided into more than 10 subtypes (1).

Nuclear factor- $\kappa \mathrm{B}(\mathrm{NF}-\kappa \mathrm{B})$ is an important signal transduction pathway associated with cell proliferation, apoptosis, tumor treatment, and immune regulation (2-4). Abnormal activation of NF- $\mathrm{KB}$ signal transduction is considered a significant feature of DLBCL (5-7), and was found to be correlated with many clinicopathological features, prognosis and response to therapy in lymphomas. Therefore, genes related to NF- $\mathrm{kB}$ activation, such as tumor necrosis factor, $\alpha$-induced protein 3 (TNFAIP3, also known as A20), mucosa-associated lymphoid tissue lymphoma translocation gene 1 (MALT1), caspase recruitment domain-containing membrane-associated guanylate kinase protein 1 (CARMA1), and B-cell leukemia/lymphoma 10 (BCL10), should be assessed in association with DLBCL.

MALT1 and A20 regulate NF- $\kappa \mathrm{B}$ activation through multiple processes $(8,9)$. A20 is located on chromosome band 6q23.3, and encodes the A20 protein, which is a negative regulator of NF- $\mathrm{KB}$. It is associated with pathogenesis, progression and therapy of several tumors. Abnormalities of A20, such as mutation and methylation, have been described in many tumors. For instance, Bavi et al (10) found that A20 alteration is prevalent in colorectal carcinoma, especially A20 promoter methylation. This results in reduced A20 protein levels, which are correlated with poor outcome in colorectal carcinoma. Genetic abnormalities of A20 have also been found in extranodal marginal zone B cell lymphoma of mucosa-associated lymphoid tissue (MALT), DLBCL, mantle cell lymphoma, and Hodgkin lymphoma $(11,12)$. In addition, high MALT1/ A20/NF-kB levels and their relationships to pathogenesis and therapy of several lymphomas have been described (13-15). However, the role of the A20 protein in DLBCL remains unclear. MALT1 is an upstream regulatory factor of A20. Because of its proteolytic activity, MALT1 also promotes NF- $\mathrm{BB}$ activation by cleaving A20 (16). Once activated, NF- $\mathrm{KB}$ regulates its target genes, including survivin, a member of the inhibitor of apoptosis protein (IAP) family. Survivin has a double function in regulating cell growth, modulating apoptosis as well 
as the cell cycle. Studies have assessed the effects of survivin on the clinicopathological course, prognosis, and treatment of lymphomas $(17,18)$. Therefore, we hypothesized that survivin affects the growth of aggressive B-cell lymphoma cells in association with abnormal activation of $\mathrm{NF}-\kappa \mathrm{B}$ resulting from MALT1 and A20.

Phorbol myristate acetate (PMA), also known as 12- $O$-tetradecanoylphorbol-13-acetate (TPA), is a potent tumor promoter. Ionomycin (IONO) is an ionophore secreted by Streptomyces conglobatus that induces calcium transport into the cell. PMA is often used in conjunction with ionomycin to stimulate immune responses (19). For instance, it was shown that PMA/IONO mimics T-cell antigen receptor signaling by activating PKC- $\theta$, and induces recruitment of $A 20$ into a complex of MALT1 and Bcl-10, leading to MALT1-mediated processing of A20 (20). In addition, PMA/IONO inhibits growth of tumor cells, inducing apoptosis (21). However, studies assessing the effect of PMA/IONO on DLBCL cells are scarce. Therefore, this study aimed to determine whether PMA/IONO affects the growth of DLBCL OCI-LY1 cells, exploring the underlying molecular mechanisms. Notably, we found that PMA/IONO promotes apoptosis and inhibits the growth of DLBCL cells, and these effects are associated with A20 upregulation.

\section{Materials and methods}

Cell culture and treatment. Diffuse large B-cell lymphoma OCI-LY1 cells were a kind gift from Dr B. Hilda (Albert Einstein College of Medicine, New York, NY, USA). They were maintained at $37^{\circ} \mathrm{C}$ in $5 \%$ carbon dioxide in Iscove's modified Dulbecco's media (IMDM) and supplemented with $10 \%$ FCS, $1 \%$ penicillin and streptomycin. Phorbol-12-myristate-13-acetate (PMA) and ionomycin (IONO) (both from Sigma-Aldrich, USA) were reconstituted in DMSO. Cells were treated with mixtures containing different concentrations of PMA and IONO (PMA/IONO). According to a previous study (20), PMA + IONO combinations were: $200 \mathrm{ng} / \mathrm{ml}+0.167 \mu \mathrm{M}, 200 \mathrm{ng} / \mathrm{ml}+1 \mu \mathrm{M}$, and $200 \mathrm{ng} / \mathrm{ml}+2 \mu \mathrm{M}$. Various treatment times were assessed, including $0.5,2,6,24,48$ and $72 \mathrm{~h}$.

MTT assay. OCILY1 cells at logarithmic growth phase $\left(1.25 \times 10^{5} / \mathrm{ml}\right)$, seeded in 96 -well plates, were incubated at $37^{\circ} \mathrm{C}$ in $5 \%$ carbon dioxide in the presence of various test drugs (PMA + IONO combinations) for 24, 48, and $72 \mathrm{~h}$. Then, MTT solution (Genview, USA) was added to each well followed by 4-h incubation; the resulting formazan crystals were dissolved by addition of DMSO. Absorbance was read at $570 \mathrm{~nm}$ on a Rayto RT-6000 microplate reader (Rayto Life and Analytical Sciences Co., Ltd., Shenzhen, China).

Cell cycle and apoptosis assays. OCI-LY1 cells (7x105/ml) were seeded in 6-well plates and incubated with $200 \mathrm{ng} / \mathrm{ml}$ PMA and $1 \mu \mathrm{M}$ IONO in combination for 24,48 , and $72 \mathrm{~h}$, respectively. After collection, cells were stained with Annexin V-FITC and propidium iodide (PI) kit (BD Biosciences, USA) in the dark for $5 \mathrm{~min}$. Finally, cell apoptosis was quantified by flow cytometry on a BD FACSAria ${ }^{\mathrm{TM}}$ III flow cytometer (BD Biosciences).
Table I. Primer sequences used in RT-qPCR.

\begin{tabular}{ll}
\hline Gene name & \multicolumn{1}{c}{ Sequence } \\
\hline Survivin & F: 5'-GCCAGATTTGAATCGCGGGA-3' \\
& R: 5'-GCAGTGGATGAAGCCAGCCT-3 \\
\multirow{3}{*}{-actin } & F: 5'-TGGCACCCAGCACAATGAA-3' \\
& R:5'-CTAAGTCATAGTCCGCCTAGAAGCA-3'
\end{tabular}

F, forward; R, reverse.

Table II. siRNA sequences for A20.

\begin{tabular}{lc}
\hline Gene name & Sequence \\
\hline siRNA-1 & 5'-CCCUCAUCGACAGAACAUTT-3' \\
siRNA-2 & 5'-AUGUUUCUGUCGAUGAGGGTT-3'
\end{tabular}

For cell cycle distribution, OCI-LY1 cells $\left(7 \times 10^{5} / \mathrm{ml}\right)$ were treated as aforementioned for apoptosis assessment. After collection, cells were fixed in $70 \%$ ethanol for $24 \mathrm{~h}$ at $4^{\circ} \mathrm{C}$, washed three times with PBS, and stained with RNase $(1 \mathrm{mg} / \mathrm{ml}$; Sigma) and PI solution $(100 \mu \mathrm{l} / \mathrm{ml})$ for $30 \mathrm{~min}$ before analysis by flow cytometry.

Quantitative real-time PCR. Total RNA was extracted from OCI-LY1 cells using TRIzol reagent (Beyotime, China) according to the manufacturer's instructions. cDNA synthesis from $2 \mu \mathrm{g}$ RNA was carried out with M-MLV Reverse Transcription kit (Invitrogen, USA). Quantitative real-time PCR was performed using $500 \mathrm{ng}$ of template, SYBR Green Master Mix $(10 \mu \mathrm{l}), 100 \mu \mathrm{M}$ of each primer (forward and reverse) and Nuclease-Free Water to $20 \mu \mathrm{l}$ final volume. Primers were designed by Premier 5.0, and are shown in Table I. Quantitative real-time PCR was performed on an ABI Real-Time PCR system 7500 Fast thermal cycler (Applied Biosystems, Inc., USA). Cycle conditions were: $50^{\circ} \mathrm{C}$ for $2 \mathrm{~min}, 95^{\circ} \mathrm{C}$ for $10 \mathrm{~min}, 40$ cycles of $95^{\circ} \mathrm{C}$ for $15 \mathrm{sec}$ and $60^{\circ} \mathrm{C}$ for $1 \mathrm{~min}$. Data were analyzed using the Sequence Detection Software version 1.6.3 supplied by Applied Biosystems (ABI); the comparative cycle threshold $(\Delta \Delta \mathrm{Ct})$ method was adopted for quantitation.

Western blotting. OCI-LY1 cells $\left(7.5 \times 10^{5}\right.$ cells $\left./ \mathrm{ml}\right)$ were treated in 6-well plates with PMA/IONO (200 ng/ml, $200 \mathrm{ng} / \mathrm{ml}+0.167 \mu \mathrm{M}$, and $200 \mathrm{ng} / \mathrm{ml}+2 \mu \mathrm{M}$ ) for $2 \mathrm{~h}$, or PMA/IONO $(200 \mathrm{ng} / \mathrm{ml}+1 \mu \mathrm{M})$ for $30 \mathrm{~min}, 2 \mathrm{~h}$ and $6 \mathrm{~h}$, respectively. Treated cells were collected and lysed with RIPA buffer on ice for $15 \mathrm{~min}$ for total protein extraction. Protein concentration was determined by the colorimetric BCA assay. Twenty micrograms of total protein from each sample was resolved by $10 \%$ SDS-PAGE and transferred onto PVDF membranes. After blocking with 5\% skimmed-milk in T-TBS, mouse anti-MALT1 polyclonal antibody (1:500), rabbit anti-survivin monoclonal antibody (1:500) (both from Santa Cruz Biotechnology, USA), mouse anti-TNFAIP3 monoclonal 
A

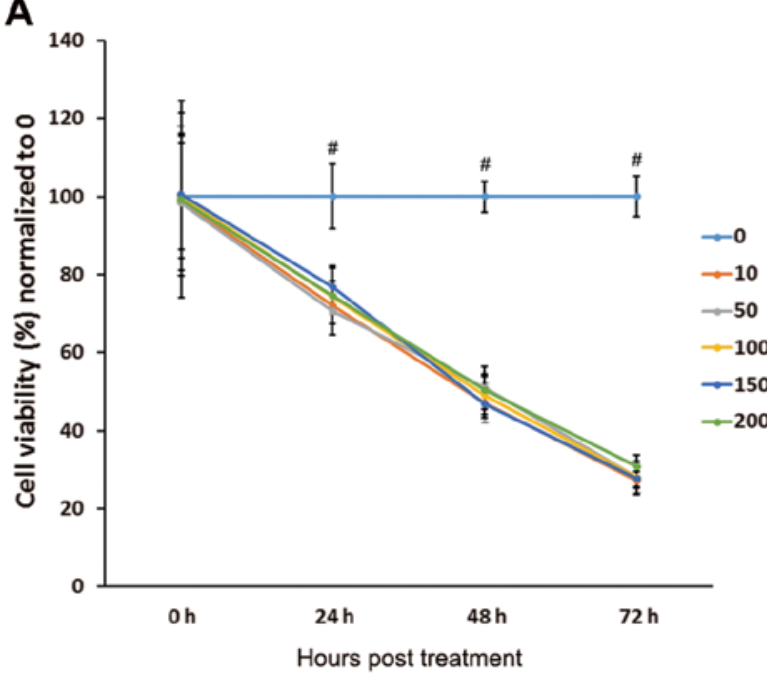

B

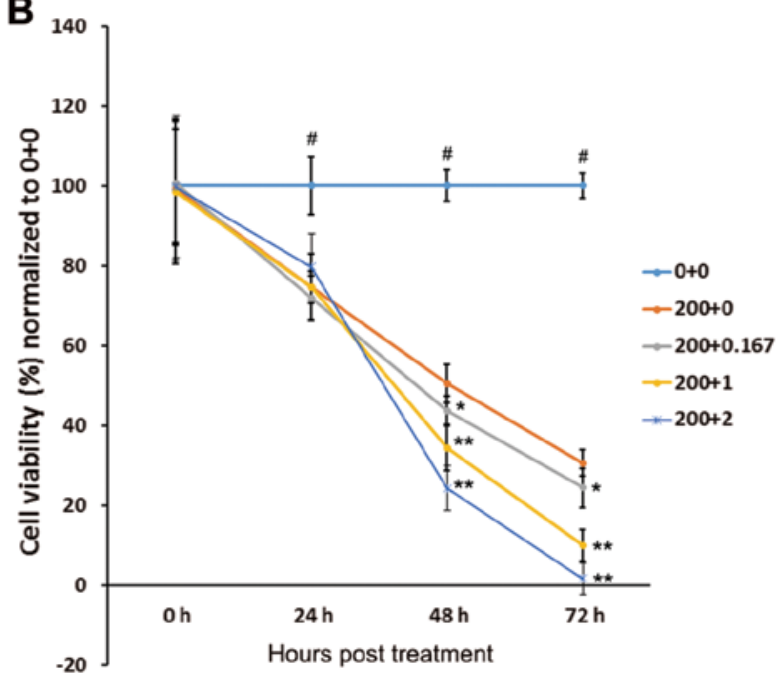

Figure 1. PMA and PMA/IONO affect OCI-LY1 cell growth. (A) Effects of PMA (ng/ml) on OCI-LY1 cell proliferation. (B) Effects of PMA/IONO (ng/ml $+\mu \mathrm{M}$ on OCI-LY1 cell growth. Values are mean $\pm \mathrm{SD}(\mathrm{n}=3) .{ }^{*} \mathrm{P}<0.05$ vs. PMA-treated cells at the same time-point; ${ }^{*} \mathrm{P}<0.05,{ }^{* *} \mathrm{P}<0.01$ vs. the $200+0$ group.

antibody (1:250; Abcam) and mouse anti- $\beta$-actin monoclonal antibody (1:1,000; Santa Cruz Biotechnology) were added overnight at $4^{\circ} \mathrm{C}$. Then, horseradish peroxidase-conjugated anti-rabbit or anti-mouse $\operatorname{IgG}(1: 3,000$; Beijing Dingguo Changsheng Biotechnology Co., Ltd., Beijing, China) was added for $1 \mathrm{~h}$ at room temperature. Western blotting detection was carried out by enhanced chemiluminescence (ECL). Quantitative analysis was performed with analysis software Image-Pro Plus (Media Cybernetics).

siRNA transfection. siRNAs for A20 were designed and synthesized by Shanghai GenePharma Co., Ltd. (China). A total of 3 specific siRNAs were transfected into OCI-LY1 cells using Lipofectamine RNAiMAX (Invitrogen) according to the manufacturer's instructions at a final concentration of $20 \mathrm{nM}$. Efficacy of knockdown was evaluated by RT-qPCR and western blot analysis. The most effective siRNA was used in subsequent experiments. The sequences of the siRNAs are shown in Table II.

Statistical analysis. Data were analyzed with SPSS 19.0 (SPSS, USA). All experiments were repeated three times. Values are reported as the mean \pm standard deviation (SD). Tests for homogeneity of variance were carried out before analysis of variance. One-way or univariate analysis of variance was used according to data characteristics. Based on normality test results, correlation analysis was performed either by the Pearson's or Spearman's method. $\mathrm{P}<0.05$ was considered to indicate a statistically significant result.

\section{Results}

PMA/IONO decreases OCI-LY1 cell proliferation. OCI-LY1 cell proliferation was analyzed by MTT assay. As shown in Fig. 1A, OCI-LY1 cell proliferation was inhibited by PMA, but not in a concentration-dependent manner. Notably, treatment with PMA/IONO resulted in markedly inhibited proliferation of the OCI-LY1 cells. For the initial 24 h, OCI-LY1 cell proliferation was similar after PMA monotherapy and treatment with the PMA/IONO combinations $(\mathrm{P}<0.05)$. However, at later time-points (48 and $72 \mathrm{~h}$ ), cell viability showed statistical differences between the PMA/IONO and PMA groups (all $\mathrm{P}<0.05$, Fig. 1B).

PMA/IONO induces apoptosis in OCI-LY1 cells. Compared with the control cells, apoptosis rates showed no significant differences after treatment with PMA/IONO for 24 and $72 \mathrm{~h}$ ( $\mathrm{P}>0.05)$; however, the apoptosis rate of OCI-LY1 cells was higher after treatment with PMA/IONO at $48 \mathrm{~h}$ compared with the controls, with $25.5 \pm 8.84$ and $7.43 \pm 1.42 \%$, respectively $(\mathrm{P}=0.015)$, as shown in Fig. 2 .

PMA/IONO treatment results in OCI-LY1 cell cycle arrest at the G0/G1 stage. Cell cycle distribution of OCI-LY1 cells was examined by flow cytometry. Distinct cell cycle distribution patterns appeared between the control and the PMA/IONO treatment groups at $24 \mathrm{~h}(\mathrm{P}<0.05)$; clearly, cells at the G0/G1 stage were markedly increased after treatment with PMA/IONO (Fig. 3). The differences were less apparent at later time-points of 48 and $72 \mathrm{~h}$ (Fig. 3). These findings indicated that PMA/IONO caused cell cycle arrest at the G0/G1 stage.

PMA/IONO induces protein expression of A20 but not MALT1 in OCI-LY1 cells. As shown in Fig. 4, treatment of OCI-LY1 cells with $200 \mathrm{ng} / \mathrm{ml}$ PMA resulted in increased A20 protein levels. However, combining PMA and IONO further induced A20 protein expression, in an IONO concentration-dependent manner (Fig. 4A). In addition, when PMA/IONO at $200 \mathrm{ng} / \mathrm{ml}$ $+1 \mu \mathrm{M}$ were assessed at different times, western blot analysis indicated that A20 protein expression was increased in a time-dependent fashion (Fig. 4B). Meanwhile, no differences in MALT1 protein levels were found among OCI-LY1 cells treated with PMA monotherapy and PMA/IONO combinations, at any concentrations or times (Fig. 4). 
A
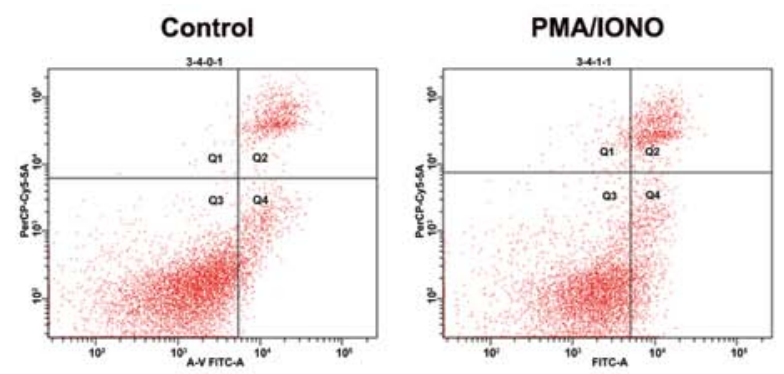

$48 \mathrm{~h}$
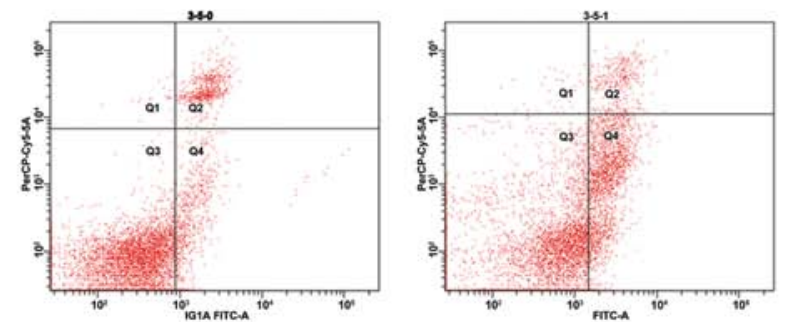

$72 \mathrm{~h}$
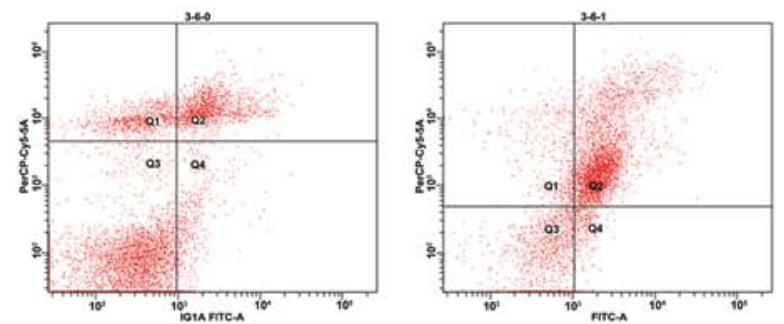

B

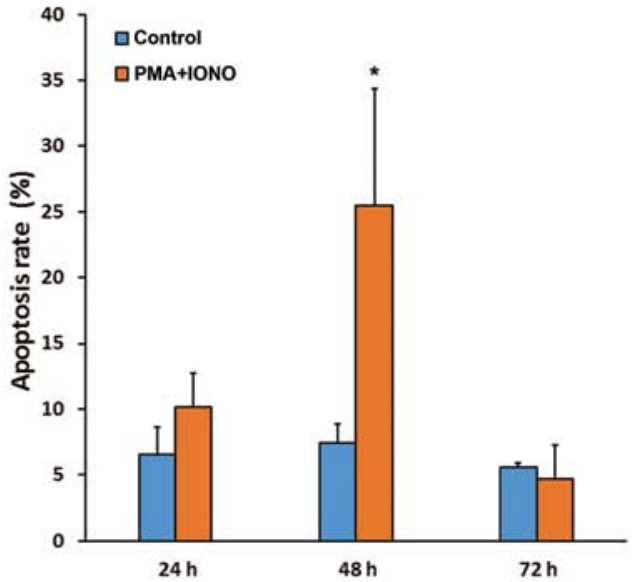

Figure 2. Effects of PMA/IONO on OCI-LY1 cell apoptosis at different times. (A) Flow cytograms of cells treated with $200 \mathrm{ng} / \mathrm{ml}+1 \mu \mathrm{M}$ PMA/IONO at different times. Q4, early apoptosis; Q2, late apoptosis. (B) Quantitation of (A). Values are presented as the mean \pm SD $(n=3)$. ${ }^{*} \mathrm{P}<0.05$ vs. control group at the same time-point.

PMA/IONO decreases survivin expression at the gene and protein levels. Survivin mRNA levels were significantly lower in OCI-LY1 cells treated for $48 \mathrm{~h}$ with PMA + IONO $(0.22 \pm 0.06)$ compared with the PMA $(0.45 \pm 0.08)$ and the control $(0.81 \pm 0.14)$ groups (all $\mathrm{P}<0.05$, Fig. $5 \mathrm{~A})$. In concordance, survivin protein amounts were lower in the OCI-LY1 cells treated with PMA + IONO $(0.37 \pm 0.02)$ compared with values obtained after treatment of PMA $(0.58 \pm 0.06)$ and no treatment $(0.52 \pm 0.07)($ all $\mathrm{P}<0.01$, Fig. $5 \mathrm{~B})$. Although a significant difference was obtained in survivin mRNA levels between the PMA and control groups $(\mathrm{P}<0.05$, Fig. 5A),
A

Control

PMA/IONO
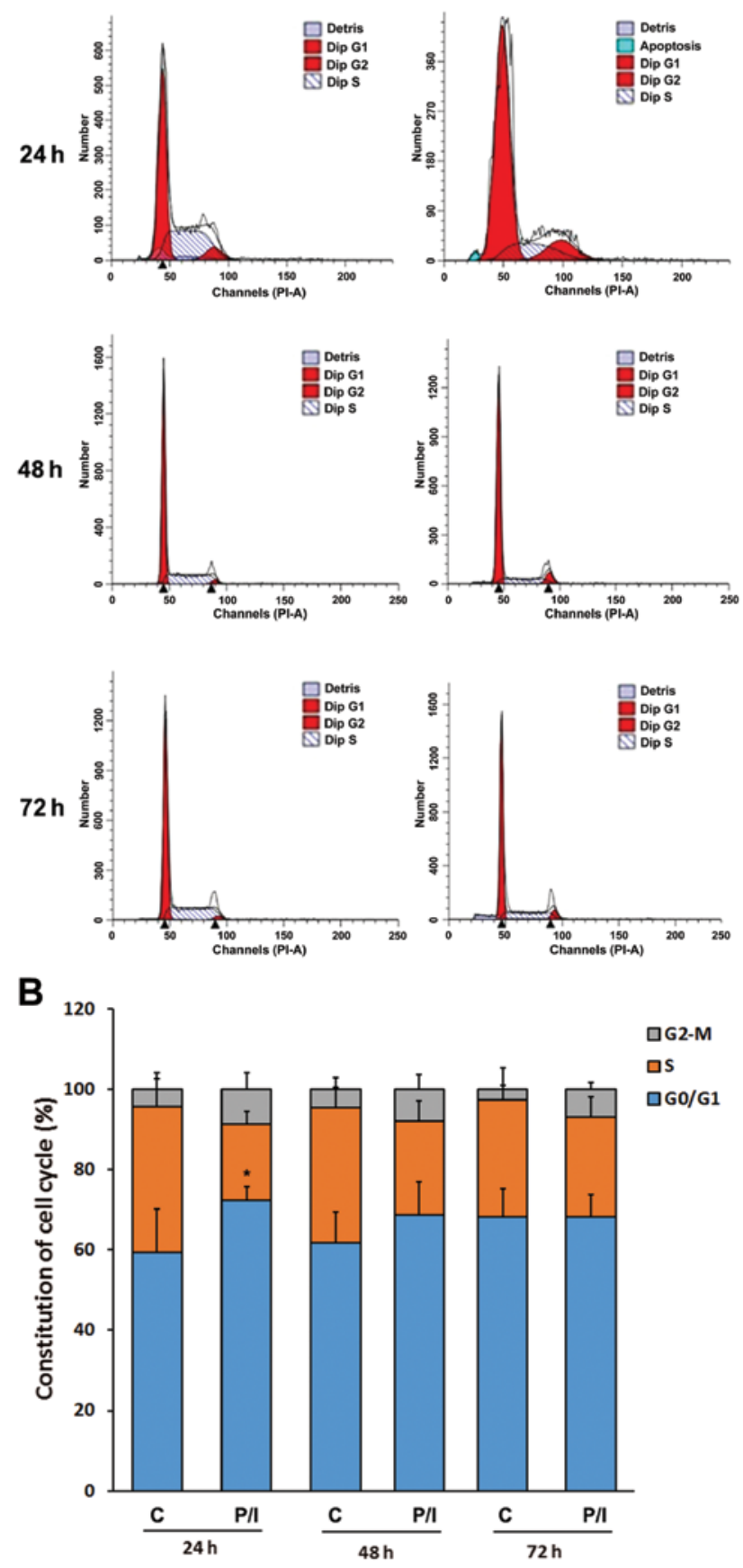

Figure 3. Effects of PMA/IONO on OCI-LY1 cell cycle distribution at different times. (A) Flow cytograms of cells treated with $200 \mathrm{ng} / \mathrm{ml}+1 \mu \mathrm{M}$ PMA/IONO for different times. (B) Quantitation of (A). Values are presented as the mean $\pm \mathrm{SD}(\mathrm{n}=3) .{ }^{*} \mathrm{P}<0.05$ vs. control group at the same time-point.

similar survivin protein amounts were obtained between the latter 2 groups ( $\mathrm{P}>0.05$, Fig. 5B).

A20 silencing increases survivin expression at the gene and protein levels. As shown in Fig. 6A, survivin mRNA levels were increased significantly in the A20-knockdown OCI-LY1 cells; however, survivin mRNA amounts were decreased in the OCI-LY1 cells after A20 silencing and treatment with PMA/IONO. Similar findings were obtained at the protein level for survivin expression (Fig. 6B). 

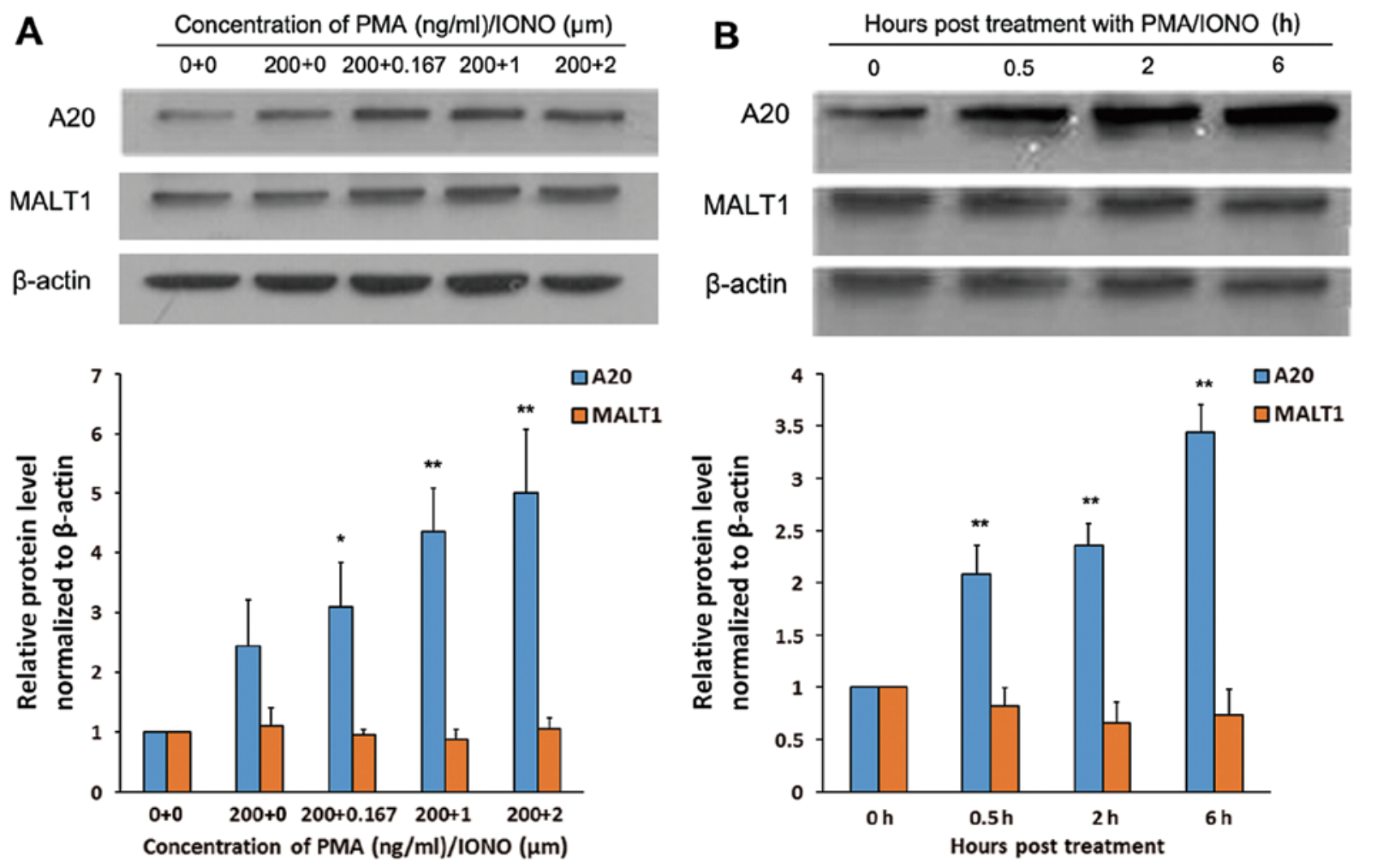

Figure 4. Effects of PMA/IONO on MALT1 and A20 protein levels at different times and concentrations. (A) A20 and MALT1 protein levels in OCI-LY1 cells treated with different PMA/IONO combinations $(0 \mathrm{ng} / \mathrm{ml}+0 \mu \mathrm{M}, 200 \mathrm{ng} / \mathrm{ml}+0 \mu \mathrm{M}, 200 \mathrm{ng} / \mathrm{ml}+0.167 \mu \mathrm{M}, 200 \mathrm{ng} / \mathrm{ml}+1 \mu \mathrm{M}, 200 \mathrm{ng} / \mathrm{ml}+2 \mu \mathrm{M})$ for $2 \mathrm{~h}$. (B) A20 and MALT1 protein levels in OCI-LY1 cells treated with PMA/IONO $(200 \mathrm{ng} / \mathrm{ml}+1 \mu \mathrm{M})$ for different times. Values are presented as the mean $\pm \mathrm{SD}$ $(\mathrm{n}=3) .{ }^{*} \mathrm{P}<0.05,{ }^{* *} \mathrm{P}<0.01$ vs. the control group at the same concentration or time-point.
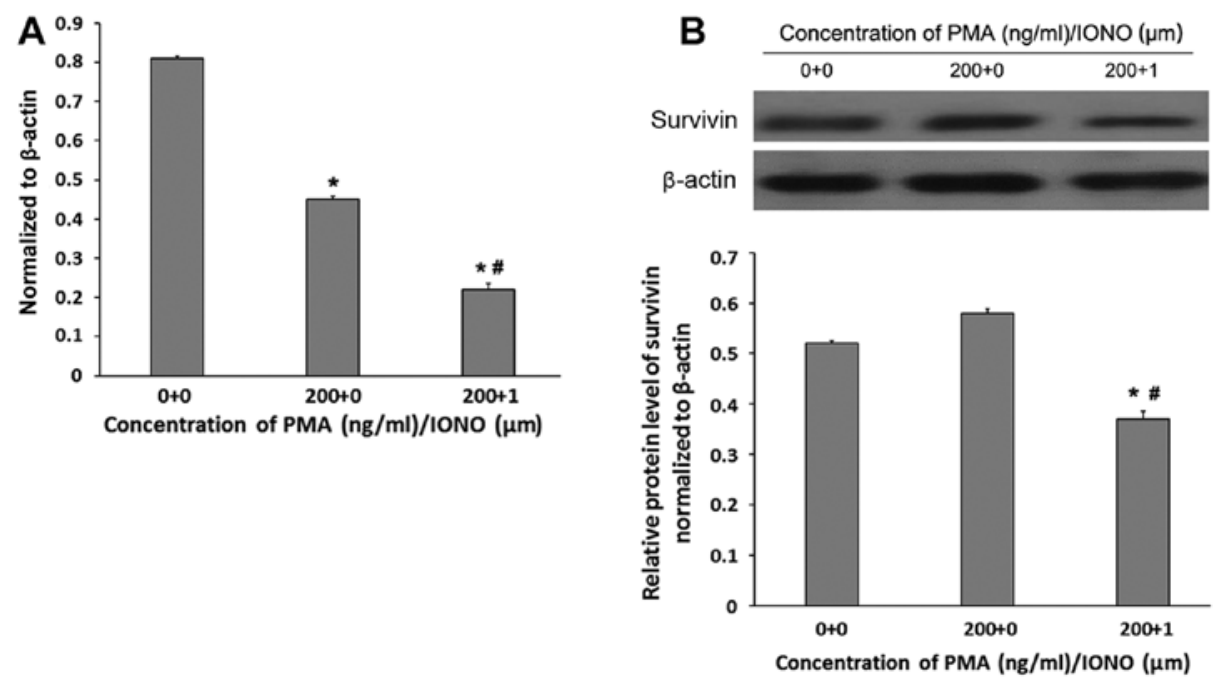

Figure 5. Survivin mRNA and protein levels after treatment with PMA/IONO at different concentrations. OCI-LY1 cells were treated with PMA/IONO at different concentrations for 4.5 h. (A) Relative survivin mRNA levels and (B) survivin protein levels. Values are presented as the mean $\pm \mathrm{SD}(\mathrm{n}=3)$. ${ }^{*} \mathrm{P}<0.05$ vs. $0+0$ group. ${ }^{~} \mathrm{P}<0.05$ vs. $200+0$ group.

\section{Discussion}

In this study, we demonstrated that PMA/IONO promotes apoptosis and inhibits the growth of DLBCL cells, and these effects are likely mediated by A20 upregulation.

At present, A-CHOP is the classical treatment for DLBCL. Because of its heterogeneity, many cases with DLBCL cannot achieve a good response to this therapy.Indeed,Zelenetz pointed out that treatment for DLBCL has exceeded A-CHOP (22). Therefore, it is important to identify new therapeutic targets for this lymphoma; some genes regulating NF- $\mathrm{kB}$ activation may be valuable in the treatment of DLBCL (23).

As aforementioned, PMA/IONO decreased OCI-LY1 proliferation, in time- and IONO concentration-dependent manners. These findings corroborate previous studies showing that PMA and IONO in combination affect the growth of T 
A

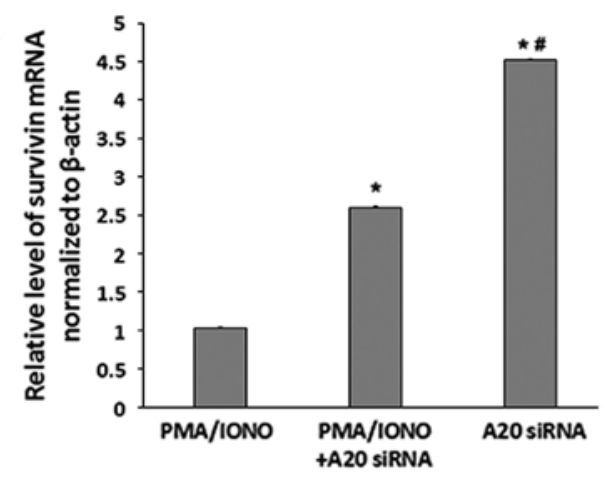

B
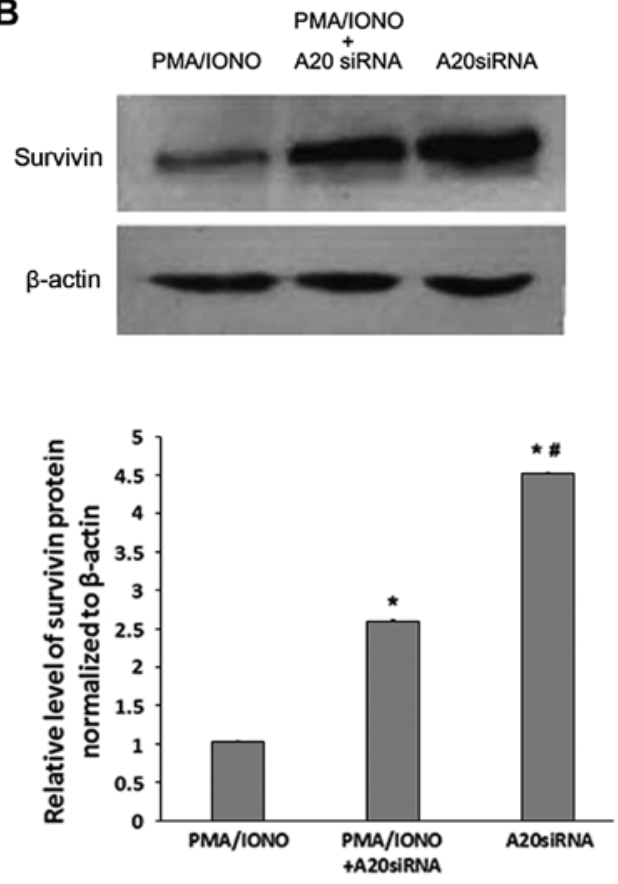

Figure 6. Effects of A20 knockdown on survivin mRNA and protein levels. OCI-LY1 cells were treated with PMA/IONO at $200 \mathrm{ng} / \mathrm{ml}+1 \mu \mathrm{M}$ with/ without A20 siRNA (20 nM) pre-treatment for $24 \mathrm{~h}$. (A) Relative survivin mRNA levels and (B) survivin protein levels. Values are represented as the mean $\pm \mathrm{SD}(\mathrm{n}=3)$. ${ }^{*} \mathrm{P}<0.05$ vs. $\mathrm{PMA} / \mathrm{IONO}$ group. ${ }^{~} \mathrm{P}<0.05$ vs. PMA/ $\mathrm{IONO}+\mathrm{A} 20$ siRNA group.

and B cells and macrophages in vitro $(24,25)$. Decreased cell proliferation might be explained by the cell cycle arrest of OCI-LY1 cells treated with PMA/IONO at the G0/G1 phase as stated above. In addition, we found that OCI-LY1 cell apoptosis was increased after treatment with PMA/IONO for $48 \mathrm{~h}$; of note this effect was not observed at $72 \mathrm{~h}$, possibly due to the overall cell death rate at this time-point for both groups. The role of A20 in DLBCL remains unclear. In this study, the relationship between PMA/IONO and the expression of various proteins, such as A20, MALT1 and survivin, in OCI-LY1 cells were also assessed.

Notably, we recently found that A20 abnormalities are involved in DLBCL cell proliferation and drug resistance, as well as poor prognosis (unpublished data). A20 expression levels in the OCI-LY1 cells were increased after treatment with PMA/IONO. Markedly, A20 protein levels increased after treatment with PMA/IONO, which caused no change in MALT1 protein expression. This finding indicates that the change in A20 protein expression is not linked to proteolytic activation by MALT1 protein in the OCI-LY1 cells treated with PMA/IONO. All in all, these results suggest that PMA/IONO induced apoptosis and decreased growth in OCI-LY1 cells and this is associated with its effects on A20 protein expression in OCI-LY1 cells. $\mathrm{Ca}^{2+}$ overload is one of the mechanisms of apoptosis of OCI-LY1 cells exposed to PMA/IONO (26). Another mechanism of apoptosis and proliferation inhibition may be associated with A20 upregulation. In this case, it is possible that A20 expression inhibits NF- $\mathrm{kB}$ activation. We also found that survivin expression was decreased in the OCI-LY1 cells after PMA/IONO treatment. The reduced survivin levels may result from inhibition of NF- $\mathrm{KB}$ signaling caused by A20 upregulation. These data were confirmed by A20 silencing in OCI-LY1 cells, which resulted in increased survivin amounts, both at the gene and protein levels.

In conclusion, this study demonstrated that PMA/IONO affects the growth of OCI-LY1 cells, an effect associated with A20 induction. As an important negative regulator, A20 also impacts progression and treatment of DLBCL possibly by inhibiting NF- $\mathrm{KB}$, indirectly inhibiting target genes such as survivin. Therefore, A20 may be considered a therapeutic target for DLBCL.

\section{Acknowledgements}

This study was supported by the National Natural Science Foundation of China (no. 81160299).

\section{References}

1. Menon MP, Pittaluga S and Jaffe ES: The histological and biological spectrum of diffuse large B-cell lymphoma in the World Health Organization classification. Cancer J 18: 411-420, 2012.

2. Pulvino M, Liang Y, Oleksyn D, DeRan M, Van Pelt E, Shapiro J, Sanz I, Chen L and Zhao J: Inhibition of proliferation and survival of diffuse large B-cell lymphoma cells by a small-molecule inhibitor of the ubiquitin-conjugating enzyme Ubc13-Uev1A. Blood 120: 1668-1677, 2012.

3. Ramachandiran S, Adon A, Guo X, Wang Y, Wang H, Chen Z, Kowalski J, Sunay UR, Young AN, Brown T, et al: Chromosome instability in diffuse large B cell lymphomas is suppressed by activation of the noncanonical NF-אB pathway. Int J Cancer 136: 2341-2351, 2015.

4. Niu M, Shen Y, Xu X, Yao Y, Fu C, Yan Z, Wu Q, Cao J, Sang W, Zeng L, et al: Piperlongumine selectively suppresses ABC-DLBCL through inhibition of NF- $\kappa B$ p65 subunit nuclear import. Biochem Biophys Res Commun 462: 326-331, 2015.

5. Staudt LM: Oncogenic activation of NF-kappaB. Cold Spring Harb Perspect Biol 2: a000109, 2010.

6. Zhang J, Grubor V, Love CL, Banerjee A, Richards KL, Mieczkowski PA, Dunphy C, Choi W, Au WY, Srivastava G, et al: Genetic heterogeneity of diffuse large B-cell lymphoma. Proc Natl Acad Sci USA 110: 1398-1403, 2013.

7. Zhao Q, Fu W, Jiang H, Du J, Zhang C, Xi H, Zhou F, Li R and Hou J: Clinicopathological implications of nuclear factor $\kappa \mathrm{B}$ signal pathway activation in diffuse large B-cell lymphoma. Hum Pathol 46: 524-531, 2015.

8. Afonina IS, Elton L, Carpentier I and Beyaert R: MALT1 - a universal soldier: Multiple strategies to ensure NF- $\kappa$ B activation and target gene expression. FEBS J 282: 3286-3297, 2015.

9. Martinez-Climent JA: The origin and targeting of mucosa-associated lymphoid tissue lymphomas. Curr Opin Hematol 21: 309-319, 2014.

10. Bavi P, Abubaker J, Al-Sanea N, Abduljabbar A, Ashari LH, Alhomoud S, Al-Dayel F, Uddin S, Siraj AK and Al-Kuraya KS: Clinico-pathological significance of TNF alpha-induced protein3 (TNFAIP3) in Middle Eastern colorectal carcinoma. Clin Epigenetics 2: 417-418, 2011. 
11. Honma K, Tsuzuki S, Nakagawa M, Tagawa H, Nakamura S, Morishima Y and Seto M: TNFAIP3/A20 functions as a novel tumor suppressor gene in several subtypes of non-Hodgkin lymphomas. Blood 114: 2467-2475, 2009.

12. Paik JH, Go H, Nam SJ, Kim TM, Heo DS, Kim CW and Jeon YK: Clinicopathologic implication of A20/TNFAIP3 deletion in diffuse large B-cell lymphoma: An analysis according to immunohistochemical subgroups and rituximab treatment. Leuk Lymphoma 54: 1934-1941, 2013.

13. Nakamura S and Matsumoto T: Helicobacter pylori and gastric mucosa-associated lymphoid tissue lymphoma: Recent progress in pathogenesis and management. World J Gastroenterol 19: 8181-8187, 2013.

14. Nocturne G, Boudaoud S, Miceli-Richard C, Viengchareun S, Lazure T, Nititham J, Taylor KE, Ma A, Busato F, Melki J, et al: Germline and somatic genetic variations of TNFAIP3 in lymphoma complicating primary Sjogren's syndrome. Blood 122 4068-4076, 2013.

15. Fontan L and Melnick A: Targeting lymphomas through MALT1 inhibition. Oncotarget 3: 1493-1494, 2012.

16. McAllister-Lucas LM, Baens M and Lucas PC: MALT1 protease: A new therapeutic target in B lymphoma and beyond? Clin Cancer Res 17: 6623-6631, 2011.

17. He C, Liu Z, Ji J and Zhu H: Prognostic value of survivin in patients with non-Hodgkin's lymphoma: A meta-analysis. Int J Clin Exp Med 8: 5847-5854, 2015.

18. Sun L, Zhao Y, Shi H, Ma C and Wei L: LMP-1 induces survivin expression to inhibit cell apoptosis through the NF- $\kappa \mathrm{B}$ and PI3K/Akt signaling pathways in nasal NK/T-cell lymphoma. Oncol Rep 33: 2253-2260, 2015.

19. Abate D, Saldan A, Forner G, Tinto D, Bianchin A and Palù G Optimization of interferon gamma ELISPOT assay to detect human cytomegalovirus specific T-cell responses in solid organ transplants. J Virol Methods 196: 157-162, 2014.
20. Coornaert B, Baens M, Heyninck K, Bekaert T, Haegman M, Staal J, Sun L, Chen ZJ, Marynen P and Beyaert R: T cell antigen receptor stimulation induces MALT1 paracaspase-mediated cleavage of the NF-kappaB inhibitor A20. Nat Immunol 9: 263-271, 2008.

21. Debernardis D, Stanzione S, Ottoboni C, Clerico L, Mancuso T, Parodi S and Russo P: Endogenous tumor necrosis factor enhances topoisomerase II inhibitors activity in human ovarian cancer cell lines. J Pharmacol Exp Ther 279: 84-90, 1996.

22. Zelenetz AD: Guidelines for NHL: Updates to the management of diffuse large B-cell lymphoma and new guidelines for primary cutaneous $\mathrm{CD} 30^{+} \mathrm{T}$-cell lymphoproliferative disorders and T-cell large granular lymphocytic leukemia. J Natl Compr Canc Netw 12 (Suppl 5): 797-800, 2014.

23. Carbone A, Gloghini A, Kwong YL and Younes A: Diffuse large B cell lymphoma: Using pathologic and molecular biomarkers to define subgroups for novel therapy. Ann Hematol 93: 1263-1277, 2014.

24. Busca A, Saxena M and Kumar A: Critical role for antiapoptotic Bcl-xL and Mcl-1 in human macrophage survival and cellular IAP1/2 (cIAP1/2) in resistance to HIV-Vpr-induced apoptosis. J Biol Chem 287: 15118-15133, 2012

25. Fritzenwanger M, Jung C, Franz M, Foerster M and Figulla HR: Immunomodulatory effects of cardiotrophin-1 on in vitro cytokine production of monocytes and $\mathrm{CD} 4^{+} \mathrm{T}-$-lymphocytes. Indian J Med Res 136: 471-476, 2012.

26. Yee J, White RE, Anderton E and Allday MJ: Latent Epstein-Barr virus can inhibit apoptosis in B cells by blocking the induction of NOXA expression. PLoS One 6: e28506, 2011. 